\title{
Erratum to: Promoter hypermethylation of RASSF1A, MGMT, and HIC-1 genes in benign and malignant colorectal tumors
}

\author{
Hamdy E. Abouzeid • Abdel Meguid Kassem • \\ Hatem A. El-mezayen • Hayaat Sharad • \\ Shimaa Abdel Rahman • Abdel Hady Abdel Wahab
}

Published online: 3 August 2011

(C) International Society of Oncology and BioMarkers (ISOBM) 2011

\section{Erratum to: Tumor Biol}

DOI 10.1007/s13277-011-0156-7

The original version of this article unfortunately contained a mistake.

Hamdy E. Abouzeid and Abdel Meguid Kassem's names have been inadvertently omitted from the author's list.

Abdel Meguid Kassem from the Faculty of Medicine Cairo University and Hamdy E. Abouzeid, Radio-biological Applications Department, Nuclear Research Center, Atomic Energy Authority are the major contributors to the research.

The online version of the original article can be found at http://dx.doi. org/10.1007/s13277-011-0156-7.

H. E. Abouzeid

Radio-Biological Applications Department,

Nuclear Research Center, Atomic Energy Authority,

Cairo, Egypt

\section{A. M. Kassem}

Tropical Medicine Department and GI-Endoscopy Unit,

Faculty of Medicine, Cairo University,

Cairo, Egypt

H. A. El-mezayen · H. Sharad - S. A. Rahman

Chemistry Department, Faculty of Science, Helwan University,

Ain Helwan,

Cairo, Egypt

H. A. El-mezayen

e-mail: hatem_mezayen@yahoo.com

\section{A. H. Abdel Wahab $(\square)$}

Cancer Biology Department, National Cancer Institute,

Cairo University,

Cairo, Egypt

e-mail: abdelhadya@gmail.com 